\title{
ANALISIS KUALITAS PEMBELAJARAN GURU KAITANNYA DENGAN HASIL BELAJAR PESERTA DIDIK DI SMP NEGERI 1 LILIRIAJA KABUPATEN SOPPENG
}

\author{
ANALYSIS OF TEACHER'S TEACHING QUALITY CORRELATED \\ TO THE STUDENT'S LEARNING OUTCOMES OF SMPN 1 \\ LILIRIAJA IN SOPPENG DISTRICT
}

\author{
Oleh \\ JUMARDIAH
}

\begin{abstract}
ABSTRAK
Penelitian ini bertujuan untuk: (1) mengetahui gambaran kualitas pelaksanaan pembelajaran guru PKn di SMPN 1 Liliriaja, (2) mengetahui hasil belajar peserta didik yang diajar oleh guru PKn di SMPN 1 Liliriaja, dan (3) mengetahui hubungan kualitas pembelajaran guru dengan hasil belajar peserta didik.

Untuk mencapai tujuan tersebut, telah dilakukan penelitian di SMP Negeri 1 Liliriaja. Sampel diambil dengan menggunakan tehnik proportionate simple random sampling. Teknik pengumpulan data menggunakan metode angket/kuisioner dan tes hasil belajar. Metode angket digunakan untuk mengungkap variabel persepsi siswa tentang kualitas pembelajaran guru PKn dan tes hasil belajar untuk mengukur variabel hasil belajar PKn peserta didik. Pengujian Instrumen dilakukan oleh tim ahli/pakar dari dosen. Uji coba empirik dilaksanakan di SMPN 1 Lilirilau. Uji validitas instrumen menggunakan uji validitas isi Gregory dan uji validitas korelasi bivariate pearson, dan uji reliabilitas mengunakan rumus percentage of agreements dan Alpha Cronbach's. Uji prasyarat analisis terdiri dari uji normalitas dan liniearitas. Uji hipotesis terdiri dari analisis regresi sederhana.

Hasil penelitian: (1) pencapaian kualitas pelaksanaan pembelajaran guru PKn di SMPN 1 Liliriaja berdasarkan persepsi siswa berada dalam kategori sangat baik, (2) pencapaian hasil belajar peserta didik yang diajar oleh guru PKn di SMPN 1 Liliriaja berada dalam kategori baik (3) terdapat hubungan positif dan signifikan Persepsi Siswa tentang Kualitas Pembelajaran Guru terhadap Hasil Belajar PKn peserta didik kelas VIII SMPN 1 liliriaja.
\end{abstract}




\begin{abstract}
This study aims to: (1) determine quality of the teaching implementation of civics education teacher at SMP 1 Liliriaja, (2) identify the learning outcomes of student who were taught by Civics at SMP 1 Liliriaja, and (3) determine the relationship between teacher teaching quality with student learning outcomes.

To achieve these objectives, the researcher conducted the survey in SMP Negeri 1 Liliriaja with a total population of 169 VIII grade students. Numbers of samples were 84 students, taken using proportionate simple random sampling technique. Data were collected using questionnaires and learning tests. Questionnaire method used to reveal the variable of students' perceptions on the teaching quality of civics teachers and learning tests to determine the civics learning outcome variables of students. Instrument testing conduced by experts/ specialists from the lecturer. Test instruments implemented in SMP 1 Lilirilau with as many as 102 students as respondents. Validity test of instrument used the Gregory content validity and bivariate Warson correlation validity, and reliability testing using the formula percentage of agreements and Alpha Cronbach's. Test requirements analysis consisted of test of normality and linearity. Hypothesis test employed a simple regression analysis.

The results: (1) the teaching implementation of civics education teacher at SMP 1 Liliriaja based on perceptions of students were in excellent category, (2) achievement of the learning outcomes of student who were taught by Civics at SMP 1 Liliriaja is the good category, and (3) there is positive and significant student perception on teachers' teaching quality with student learning outcomes of students at VIII grade of SMPN 1 Liliriaja.
\end{abstract}

\title{
I. PENDAHULUAN
}

\subsection{Latar Belakang}

Pendidikan adalah usaha sadar untuk menumbuhkan potensi sumber daya manusia melalui kegiatan pengajaran. UU Sistem Pendidikan Nasional No. 20 tahun 2003, menyatakan, bahwa tujuan pendidikan nasional adalah mencerdaskan kehidupan bangsa dan mengembangkan manusia Indonesia seutuhnya yaitu manusia yang bertakwa terhadap Tuhan Yang Maha Esa dan berbudi pekerti luhur, memiliki pengetahuan dan keterampilan, kesehatan jasmani dan rohani, kepribadian yang mantap dan mandiri serta tanggung jawab kemasyarakatan dan kebangsaan.

Dalam rangka meningkatkan kualitas pendidikan nasional, pemerintah telah melakukan berbagai upaya seperti halnya pengembangan dan penyempurnaan 
kurikulum, pengembangan materi pembelajaran, perbaikan sistem evaluasi, pengadaan buku dana alat-alat pelajaran, perbaikan sarana prasarana pendidikan, peningkatan kompetensi guru, serta peningkatan mutu pimpinan sekolah.

Dalam konteks program pendidikan di sekolah, salah satu indikator keberhasilan program pendidikan dapat dilihat dari hasil belajar yang dicapai siswa. Hasil belajar merupakan pengukuran dan penilaian hasil yang telah dilakukan oleh siswa setelah siswa melakukan kegiatan proses pembelajaran yang kemudian dibuktikan dengan suatu tes dan hasil pembelajaran tersebut dinyatakan dalam bentuk simbol baik dalam bentuk angka, huruf maupun kalimat yang menceritakan hasil yang sudah dicapai. Dalam pendidikan formal, dengan hasil belajar dapat diketahui kedudukan siswa yang pandai, sedang, atau lambat. Dengan mengetahui hasil belajar yang berbeda-beda maka dapat diketahui pula bahwa pemahaman peserta didik dalam melaksanakan proses pembelajaran berbeda-beda pula.

Pencapaian hasil belajar yang tinggi oleh siswa tidak bisa dilepaskan dari standar proses yang menampilkan kualitas layanan pembelajaran. Untuk itu pencapaian hasil belajar siswa tidak dapat dielakkan dari keharusan menganalisis setiap komponen yang dapat membentuk dan mempengaruhi hasil belajar peserta didik. Kurang optimalnya hasil belajar diperkirakan karena adanya persepsi siswa tentang metode kualitas pembelajaran yang dilaksanakan oleh guru yang masih kurang baik. Beberapa siswa kurang aktif sewaktu kegiatan belajar mengajar. Hal tersebut mengindikasikan bahwa siswa kurang senang terhadap kegiatan belajar mengajar yang di berikan oleh guru. Pada umumnya siswa yang memiliki persepsi positif terhadap kualitas pembelajaran guru akan merasa senang dalam mengikuti pelajaran sehingga siswa akan memperhatikan guru ketika menyampaikan materi pelajaran dan ikut serta aktif dalam kegiatan pembelajaran. Jika siswa memiliki persepsi negatif terhadap metode mengajar guru, maka siswa kurang memperhatikan materi yang diajarkan oleh guru dan sulit untuk memahami apa yang akan diajarkan oleh guru sehingga akan mempengaruhi hasil belajar siswa yang rendah. 
Pelaksanaan proses belajar mengajar merupakan kejadian atau peristiwa interaksi antara pendidik dan peserta didik yang diharapkan menghasilkan perubahan pada peserta didik, dari belum mampu menjadi mampu, dari belum terdidik menjadi terdidik, dari belum kompeten menjadi kompeten. Agar dapat memancing siswa untuk terlibat aktif dalam kegiatan belajar-mengajar, guru dituntut untuk lebih kreatif dalam menyelenggarakan kegiatan pembelajaran, di antaranya adalah dengan menguasai dan dapat menerapkan berbagai metode pembelajaran dan menggunakan berbagai sumber belajar yang sesuai dengan materi yang akan disampaikan, sehingga dapat tercipta kondisi pembelajaran yang baik di kelas dan tujuan pembelajaran yang telah ditetapkan dapat tercapai dengan baik. Pembelajaran dikatakan berkualitas apabila tujuan pembelajaran yang telah ditetapkan tercapai dengan baik. Kualitas pembelajaran dapat berpengaruh terhadap kemampuan siswa dalam belajar. Salah satu faktor yang dapat mempengaruhi kemampuan siswa dalam belajar adalah kemampuan siswa dalam mempersepsi materi pelajaran yang diterimanya di sekolah.

Tingkat efektivitas pembelajaran sangat dipengaruhi oleh perilaku pendidik. Perilaku pendidik yang efektif, antara lain mengajarnya jelas, menggunakan variasi metode pembelajaran, menggunakan variasi media/alat peraga pendidikan, antusiasme, memberdayakan peserta didik, menggunakan konteks sebagai sarana pembelajaran (contextual-teaching and learning), menggunakan jenis pertanyaan yang membangkitkan, dan lain sebagainya. Pendekatan proses belajar mengajar akan menekankan pada student centered, reflective learning, active learning, enjoyble dan joyful learning, cooperative learning, quantum learning, learning revolution, dan contectual learning.

Untuk menunjang fungsi strategis pendidikan PKn, perlu dituntut guru mampu melakukan pengelolaan pembelajaran PKn secara berkualitas. Bahwa mengajar guru dikatakan berkualitas apabila seorang guru dapat menampilkan kelakuan yang baik dalam usaha mengajarnya. Kelakuan tersebut diharapkan mencerminkan kemampuan guru dalam mengelola proses belajar mengajar yang 
berkualitas yang meliputi kemampuan dalam mengunakan metode dan strategi, menggunakan media dan interaksi dengan siswa berjalan dengan baik.

\subsection{Rumusan Masalah}

Berdasarkan latar belakang masalah yang telah dijelaskan di atas, maka permasalahan dalam penelitian ini dirumuskan sebagai berikut:

1. Bagaimana gambaran kualitas pelaksanaan pembelajaran guru PKn berdasarkan persepsi peserta didik di SMPN 1 Liliriaja Kabupaten Soppeng?

2. Seberapa besarkah hasil belajar PKn peserta didik di SMPN 1 Liliriaja Kabupaten Soppeng?

3. Apakah terdapat hubungan yang positif kualitas pembelajaran guru PKn terhadap hasil belajar PKn peserta didik?

\subsection{Tujuan Penelitian}

Berdasarkan fokus masalah yang ada, maka tujuan yang diharapkan dapat dicapai dalam penelitian ini adalah:

1. Untuk mengetahui gambaran kualitas pelaksanaan pembelajaran guru PKn berdasarkan persepsi peserta didik di SMPN 1 Liliriaja Kabupaten Soppeng.

2. Untuk mengetahui hasil belajar peserta didik yang diajar oleh guru PKn di SMPN 1 Liliriaja

3. Untuk mengetahui hubungan kualitas pembelajaran guru PKn terhadap hasil belajar PKn peserta didik.

\section{TINJAUAN PUSTAKA}

\subsection{Kualitas Pembelajaran}

\subsubsection{Defenisi Kualitas Pembelajaran}

Sallis Edward (1993:34) kualitas dapat di definisikan sebagai sesuatu yang melebihi kepuasan dan keinginan konsumen. Menurut Juran dalam bukunya Tjiptono Fandy (1995:9) kualitas adalah produk yang memiliki keistimewaan, membebaskan konsumen dari rasa kecewa akibat kegagalan. Produk adalah kesesuaian dengan tujuan atau mamfaatnya. Menurut Crosby (1979) bahwa "kualitas adalah kesesuaian 
dengan kebutuhan pelanggang”. Menurut Deming (1982) bahwa "kualitas harus dapat memenuhi kebutuhan pelanggan sekarang dan dimasa datang”. Perbedaan pengertian seperti dikemukakan menyebabkan kita perlu memahaminya dengan sungguhsungguh supaya mendapat gambaran yang jelas.

Pengertian kualitas secara garis besar berorientasi kepada memberi kepuasan kepada pelanggan yang menjadi tujuan organisasi, pelanggan ditempatkan sebagai raja.

Pembelajaran secara umum adalah suatu kegiatan yang dilakukan oleh guru sedemikian rupa, sehingga terjadi perubahan pada siswa ke arah yang lebih baik. Menurut Darsono (2000:135) pembelajaran merupakan proses yang direncanakan dan dilaksanakan sebagai suatu system dengan menggunakan metode dan teknik tertentu dalam memacu interaksi siswa dengan lingkungan belajar yang sudah diatur sehinnga memperlihatkan hasil dan proses yang seimbang. Oemar (1999:57) juga menambahkan bahwa: "pembelajaran adalah suatu kombinasi yang tersusun meliputi unsur-unsur manusiawi, material, fasilitas, perlengkapan dan prosedur yang saling mempengaruhi dalam mencapai tujuan pembelajaran". Iskandar \& Rudi (2017) Suatu pembelajaran yang aktif ditandai oleh sifatnya yang menekankan pada pemberdayaan siswa secara aktif. Pembelajaran bukan sekedar penekanan pada penguasaan pengetahuan tentang apa yang akan diajarkan, akan tetapi lebih menekankan pada pemahaman sehingga tertanam dan berfungsi sebagai muatan nurani dan dihayati serta diperaktekkan dalam kehidupan oleh siswa (Mulyasa, 2002:30); Iskandar \& H, (2018).

Dari beberapa definisi tersebut dapat disimpulkan bahwa pembelajaran adalah suatu kegiatan yang melibatkan guru, siswa dan komponen lainnya dalam proses pembelajaran yang saling mempengaruhi satu sama lain dalam rangka tercapainya tujuan pembelajaran yang telah dirumuskan.

Menurut Degang (1989:175); Iskandar (2016) kualitas pembelajaran selalu terkait dengan penggunaan metode pengajaran yang oftimal untuk mencapai tujuan pembelajaran, dibawah kondisi pengajaran tertentu. Ini berarti, untuk mencapai 
kualitas pembelajaran yang tinggi, bidang studi harus diorganisasi dengan strategi pengorganisasian yang tepat, yang selanjutnya disampaikan kepada siswa dengan strategi penyampaian yang tepat pula. Sudjana (1991); Iskandar (2017) menyatakan bahwa "Kondisi pembelajaran yang berkualitas dipengaruhi oleh faktor-faktor; tujuan pengajaran yang jelas, bahan pengajaran yang memadahi, metodologi pengajaran yang tepat, dan cara penilaian yang baik”. Yang dimaksud dengan bahan pengajaran disini adalah seperangkat materi keilmuan yang terdiri atas fakta, konsep, prinsip, generalisasi suatu ilmu pengetahuan yang bersumber dari kurikulum. Saat ini hal-hal tersebut merupakan suatu kompetensi yang harus dimiliki oleh siswa.

Pembelajaran yang berkualitas harus memiliki ciri yaitu:

1) Menyenangkan: siswa mengikuti pembelajaran dengan perasaan riang, gembira dan bahagia sehingga siswa terlibat penuh, antusias dan ceria.

2) Memuaskan: kebutuhan \& rasa ingin tahu dari siswa terpenuhi sehingga mereka mau kembali belajar. Dari sisi guru, indikator pencapaian terpenuhi sehingga juga muncul kepuasan.

3) Membekas: apa yang diajarkan secara kognitif membekas di pikiran siswa sehingga tidak akan lupa. Selain itu secara afektif dan psikomotorik akan membentuk perilaku baru pada siswa menjadi lebih baik.

Agar guru dapat mengajar yang berkualitas maka guru dalam setiap pembelajarannya harus:

1) Attraktif : menarik perhatian sehingga siswa mau, senang dan aktif belajar

2) Interaktif: dapat mengajar dengan kreatif dan efektif sehingga siswa menguasai ilmu yang dipelajari

3) Inspiratif: dapat menggugah dan memotivasi siswa untuk terus mencintai, mengembangkan dan menyebarkan ilmunya.

Dari beberapa pendapat di atas, yang dimaksud dengan pembelajaran yang berkualitas adalah suatu pembelajaran yang dapat memberikan pengalaman belajar yang menyenangkan, memuaskan serta membekas secara mendalam kepada anak dengan bimbingan guru yang atraktif, interaktif dan inspiratif. 


\subsubsection{Indikator Kualitas Proses Pembelajaran}

Untuk mengetahui tingkat kualitas pembelajaran dalam kegiatan belajar mengajar, maka perlu diketahui dan dirumuskan indikator-indikator kualitas pembelajaran. Iskandar (2013) Kualitas pembelajaran guru dikatakan baik apabila guru; (1) mampu membuka pelajaran, (2) mampu menyajikan materi, (3) mampu menggunakan metode, (4) mampu menggunakan media/ alat peraga, (5) mampu menggunakan bahasa yang komunikatif, (6) mampu memotivasi siswa, (7) mampu mengorganisasikan kegiatan, (8) mampu berinteraksi secara komunikatif dengan siswa, (9) mampu memberikan umpan balik, (10) mampu melaksanakan penilaian dan, (11) mampu menutup pembelajaran.

\subsection{Persepsi Peserta didik}

Kata "persepsi” berasal dari bahasa Inggris yakni kata "perception”. Kata “perception” atau persepsi berarti pengalaman tentang obyek, peristiwa, dan hubungan-hubungan yang diperoleh dengan menyimpulkan informasi dan menafsirkan pesan.

Bimo Walgito (2002:87-88) mendefinisikan bahwa "Persepsi adalah suatu proses yang didahului oleh penginderaan, yaitu merupakan proses yang berwujud diterimanya stimulus oleh individu melalui alat reseptornya”. Menurut Rakhmat, J (2001:51) menyatakan bahwa "Persepsi adalah proses pemberian arti terhadap lingkungan seorang individu, persepsi juga meliputi pengetahuan”. Menurut Sobur, A (2003:451) persepsi adalah proses menerima, menyeleksi, mengorganisasikan, mengartikan, menguji, dan memberikan reaksi kepada rangsangan pancaindera atau data. Rudolph F. Verbender dalam Alex Sobur, (2003: 446) yang menyatakan bahwa persepsi adalah proses menafsirkan informasi indrawi. Sementara Slameto (2003:102) menyatakan bahwa: Persepsi adalah proses menyangkut masuknya pesan atau informasi ke dalam otak manusia. Melalui persepsi, manusia terus menerus mengadakan hubungan dengan lingkungannya. Hubungan ini dilakukan lewat inderanya, yaitu indera penglihat, pendengar, peraba, perasa dan pencium. Learner 
dalam Abdurrahman, M (2003:151) yang mendefinisikan persepsi adalah batasan yang digunakan pada proses memahami dan mengintepretasikan informasi sensoris atau kemampuan intelek untuk merencanakan makna dari data yang diterima dari berbagai indra.

Dari pendapat para ahli di atas dapat disimpulkan, persepsi merupakan proses perlakuan seseorang terhadap objek atau informasi yang diterima melalui pengamatan dengan menggunakan indra yang dimiliki. Proses persepsi ini berkaitan dengan pemberian arti atau makna serta mengintepretasikan objek yang diamati. Dengan demikian, apa yang diperhatikan oleh individu akan betul-betul disadari oleh individu tersebut. Oleh karena itu perhatian dan kesadaran akan mempunyai hubungan yang positif, artinya apabila suatu obyek makin jelas diperhatikan maka akan semakin disadari pula obyek tersebut dan semakin jelas bagi individu. Tanpa adanya perhatian, tidak akan terjadi persepsi, karena pada awal pembentukan persepsi orang telah menentukan apa yang menjadi perhatian dirinya.

Noeng Muhadjir dalam Arif Rohman (2009:105) mengemukakan pada hakikatnya aktivitas pendidikan selalu berlangsung dengan melibatkan pihak-pihak sebagai aktor penting yang ada di dalam altivitas pendidikan, aktor penting tersebut adalah subjek yang memberi disebut pendidik, sedangkan subjek yang menerima disebut peserta didik.

Istilah peserta didik pada pendidikan formal di sekolah jenjang dasar dan menengah dikenal dengan nama anak didik atau siswa. Siswa merupakan subjek yang menerima apa yang disampaikan oleh guru. Sosok siswa umumnya merupakan sosok anak yang membutuhkan bantuan orang lain untuk bisa tumbuh dan berkembang ke arah kedewasaan. Dengan demikian siswa adalah anggota masyarakat yang berusaha mengembangkan potensi diri melalui pendidikan.

Persepsi peserta didik merupakan proses perlakuan peserta didik terhadap informasi tentang suatu objek melalui pengamatan dengan indra yang dimiliki, sehingga siswa dapat memberi arti serta mengintepretasikan objek yang diamati. 


\subsection{Hasil Belajar}

Dalam pengertian umum, belajar merupakan suatu aktivitas yang menimbulkan perubahan yang relatif permenen sebagai akibat dari upaya-upaya yang dilakukannya . Menurut Depdiknas (2002:98) kegiatan belajar merupakan kegiatan aktif yang ditunjukkan siswa baik menyangkut aspek kognitif, skill, maupun pemantapan sikap, kepribadian serta budi pekerti seperti rasa tanggung jawab, jujur, menghayati pendapat atau karya orang lain. Ibrahim (2000:21) menyebutkan belajar berdasarkan pengalaman, dimana pengalaman memberi sumbangan berupa wawasan, pemahaman dan teknik-teknik yang sulit untuk dipaparkan kepada seseorang yang tidak memiliki pengalaman serupa. Selanjutnya oleh Winkel dikatakan belajar adalah suatu aktivitas mental/psikis yang berlangsung dalam interaksi aktif dengan lingkungan yang menghasilkan sejumlah perubahan dalam pengetahuan-pemahaman, keterampilan dan nilai-sikap.

Berdasarkan berbagai pendapat tentang belajar yang telah dikemukakan sebelumnya maka belajar dapat ditinjau dari dua aspek yaitu; (1) dari aspek perubahan tingkah laku, dan (2) dari aspek kognitif. Dari aspek tingkah laku, kegiatan belajar dapat dilihat dari ciri-ciri sebagai berikut; (a) belajar merupakan kegiatan yang dilakukan individu yang menghasilkan perubahan tingkah laku pada dirinya, (b) perubahan tersebut ditandai dengan diperolehnya kemampuan, pengetahuan, sikap, dan keterampilan baru, (c) kemampuan-kemampuan yang telah diperoleh sifatnya relatif menetap dalam diri individu yang belajar. Dari aspek kognitif, belajar dapat dilihat dari ciri-ciri sebagai berikut: (a) belajar merupakan proses pemetaan informasi dengan konsep yang relevan pada struktur kognitif, (b) belajar lebih menekankan pada aspek intrinsik, yang terdiri ingatan, retensi, pengolahan informasi dengan menggunakan strategi kognitif, (c) tindakan atau tingkah laku yang muncul merupakan akibat dari hasil pemikiran yang mendorong untuk melakukan suatu aktivitas.

Hasil belajar merupakan salah satu unsur penting dalam suatu pembelajaran. Hasil belajar adalah prestasi dan respons berupa kesan-kesan yang mengakibatkan 
perubahan dalam diri individu sebagai hasil dari aktivitas dalam belajar. Proses belajar mengajar yang terjadi di sekolah merupakan salah satu upaya yang diharapkan merupakan kegiatan pembelajaran dalam rangka pencapaian hasil belajar yang maksimal. Definisi Hasil Belajar Siswa Menurut Para Ahli, Hasil belajar adalah kemampuan- kemampuan yang dimiliki siswa setelah menerima pengalaman belajarnya (Sudjana, 2004:22). Sedangkan menurut Horwart Kingsley dalam bukunya Sudjana membagi tiga macam hasil belajar mengajar : (1) Keterampilan dan kebiasaan, (2) Pengetahuan dan pengarahan, (3) Sikap dan cita-cita (Sudjana 2004:22).

Berdasarkan pengertian hasil belajar yang dikemukakan sebelumnya dapat disimpulkan bahwa hasil belajar PKn adalah hasil yang dicapai oleh seorang siswa setelah mengikuti proses belajar mengajar PKn dalam waktu tertentu yang dapat diketahui dengan memberikan tes hasil belajar sebagai alat penilaian prestasi dan angket respons.

\subsection{KERANGKA BERPIKIR}

\section{Hubungan Kualitas Pembelajaran Berdasarkan Persepsi Peserta Didik dengan} Hasil Belajar

Pencapaian hasil belajar oleh siswa tidak bisa dilepaskan dari standar proses yang menampilkan kualitas layanan pembelajaran. Untuk itu pencapaian hasil belajar siswa tidak dapat dielakkan dari keharusan menganalisis setiap komponen dalam kualitas pembelajaran. Persepsi pesera didik tentang kualitas pembelajaran guru merupakan proses peserta didik menerima dan menanggapi kualitas pembelajaran guru dalam melaksanakan kegiatan pembelajaran di kelas agar tercipta suatu kondisi belajar yang efektif. Pesrta didik memiliki persepsi yang berbeda-beda satu dengan yang lainnya, yaitu persepsi yang tinggi atau persepsi yang rendah. Peserta didik yang mempunyai persepsi yang tinggi terhadap kualitas pembelajaran akan memiliki antusias yang tinggi pada saat mengikuti pelajaran akan meningkat. Sebaliknya pada peserta didik yang mempunyai persepsi yang rendah, ia kurang antusias saat mengikuti pelajaran sehingga hasil belajar akan menurun. Dengan kualitas 
pembelajaran guru yang baik dan profesional, diduga memiliki hubungan positif terhadap hasil belajar peserta didik

\subsection{HIPOTESIS PENELITIAN}

Berdasarkan kerangka berpikir di atas maka dapat diajukan hipotesis “terdapat hubungan positif kualitas pelaksanaan pembelajaran guru PKn dengan hasil belajar PKn peserta didik”.

\section{METODE PENELITIAN}

\subsection{Jenis Dan Lokasi Penelitian}

Penelitian ini termasuk dalam penelitian ex-post-facto, karena peneliti berhubungan dengan variabel yang telah terjadi dan tidak perlu memberikan perlakuan terhadap variabel yang diteliti. Pendekatan yang digunakan adalah pendekatan kuantitatif yang artinya semua informasi atau data yang diperoleh diwujudkan dengan angka dan analisis yang digunakan adalah analisis statistik.

Lokasi penelitian ini dilaksanakan pada sekolah SMP Negeri 1 Liliriaja Kabupaten Soppeng.

\subsection{Variabel penelitian}

Variabel yang akan diselidiki dalam penelitian ini terdiri dari satu variabel bebas tentang kualitas pelaksanaan pembelajaran dan satu variabel terikat yaitu hasil belajar.

Hubungan antara variabel digambarkan sebagai berikut:

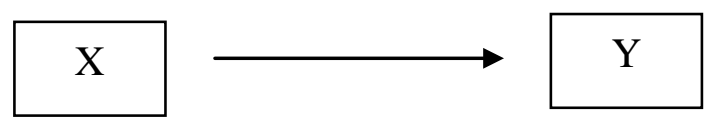

Keterangan:

$\mathrm{X}=$ Persepsi peserta didik tentang Kualitas Pembelajaran Guru PKn $\mathrm{Y}=$ Hasil Belajar PKn 


\subsection{Definisi Variabel Penelitian}

\subsubsection{Definisi Konseptual Variabel}

a. Kualitas Pelaksanaan Pembelajaran guru PKn yang dimaksud dalam penelitian ini adalah suatu pembelajaran yang dapat memberikan pengalaman belajar yang menyenangkan, memuaskan serta membekas secara mendalam kepada anak didik dengan bimbingan guru yang atraktif, interaktif dan inspiratif.

b. Hasil belajar PKn yang dimaksud dalam penelitian ini adalah segenap kemampuan yang diperoleh peserta didik setelah mengikuti pembelajaran pada mata pelajaran PKn dalam rentang waktu tertentu dan berdasarkan pada kompetensi dasar.

\subsubsection{Definisi Operasional Variabel}

a. Kualitas pelaksanaan pembelajaran PKn adalah sebagai skor yang diperoleh dari angket yang berisi kemampuan mengajar yang dimiliki oleh guru-guru PKn melalui persepsi peserta didik.

b. Hasil belajar PKn peserta didik adalah skor yang diperoleh oleh peserta didik setelah melalui suatu pengujian yang menggunakan instrumen tes hasil belajar PKn dalam bentuk pilihan ganda biasa. Skor tersebut mencerminkan kemampuan siswa sebagai hasil pembelajaran PKn dalam suatu periode tertentu.

\subsection{Populasi dan Sampel}

Populasi dalam penelitian ini adalah seluruh siswa Kelas VIII SMP Negeri 1 Liliriaja Kabupaten Soppeng Tahun ajaran 2012/2013. Populasi berjumlah 169 siswa terdiri dari 6 kelas.

Tehnik pengambilan sampel yang digunakan adalah proportionate simple random sampling. Masing-masing kelas diambil secara proporsional 50\% sehingga diperoleh jumlah sampel sebanyak 84 siswa. Anggota sampel diambil secara acak sederhana dari masing-masing kelas. 


\subsection{Teknik Pengumpulan Data}

Teknik pengumpulan data yang digunakan dalam penelitian ini adalah sebagai berikut:

1. Kuesioner (angket). Untuk memperoleh data mengenai Kualitas Pelaksanaan Pembelajaran Guru PKn

2. Tes. Tes dilakukan untuk memperoleh data mengenai variabel Hasil Belajar PKn yang dikembangkan sesuai dengan kaidah pengembangan hasil belajar.

\subsection{Instrumen Penelitian}

Instrumen angket yang digunakan untuk memperoleh data mengenai variabel kualitas pelaksanaan pembelajaran guru berupa daftar pertanyaan yang menyangkut kemampuan mengajar tersebut dalam melaksanakan pengajaran yang dibuat dengan angket tertutup. Instrumen tes hasil belajar PKn dalam bentuk pilihan ganda biasa. Tes tersebut disusun oleh peneliti berdasarkan kisi-kisi instrumen yang telah ditetapkan. Skor dari tes tersebut mencerminkan kemampuan siswa sebagai hasil pembelajaran PKn.

Sebelum instrumen ini digunakan terlebih dahulu diujicobakan pada kelompok siswa lain yang karakteristiknya sama dengan kelompok siswa yang akan dijadikan subyek penelitian yang sesungguhnya. Hal ini dimaksudkan untuk menguji validitas dan reliabilitas instrumen, selanjutnya berguna sebagai dasar dalam memilih dan menentukan butir-butir tes yang berkualitas

Uji validitas instrumen dimaksudkan untuk menentukan sejauh mana ketepatan dan kecermatan instrumen kualitas pelaksanaan pembelajaran yang disusun mengukur apa yang hendak diukur. Dalam mengkaji validitas instrumen yang disusun untuk penelitian ini maka ada tiga jenis validitas yang diuji, yaitu validitas isi, validitas konstruk dan validitas emperik.

Reliabilitas adalah indeks yang menunjukkan sejauh mana alat pengukuran dapat dipercaya atau diandalkan. Oleh karena itu dilakukan uji kekonsistenan internal (reliabilitas) baik secara rasional maupun secara empiris. 


\subsection{Teknik Analisis Data}

Setelah data penelitian ini terkumpul, maka data dianalisis dengan analisis deskriptif dan analisis inferensial.

Analisis deskriptif digunakan untuk mendeskripsikan data penelitian secara umum. Analisis deskriptif dalam hal ini menunjuk pada; (1) perhitungan ukuran tendensi sentral yang meliputi rerata (mean), modus dan median, (2) ukuran tendensi penyebaran meliputi: simpangan baku dan varians,(3) penyajian data dalam bentuk tabel distribusi frekuensi, dan (4) identifikasi kategori tingkat kecenderungan

Adapun analisis inferensial digunakan untuk menguji hipotesis penelitan. Sebelum tahap pengujian hipotesis, untuk memenuhi persyaratan tersebut, harus dipenuhi beberapa analisis, diantaranya uji normalitas dan uji linieritas. Teknik analisis regresi digunakan untuk menguji ada tidaknya hubungan antara satu variabel bebas dengan variabel terikat (uji hipotesis).

\section{HASIL PENELITIAN DAN PEMBAHASAN}

\subsection{Deskripsi Data Hasil Penelitian}

Data hasil penelitian terdiri dari variabel bebas yaitu Kualitas pembelajaran Guru PKn (X), dan variabel terikat yaitu Hasil Belajar PKn (Y). Deskripsi data masing-masing variabel secara rinci dapat dilihat dalam uraian berikut ini:

\subsubsection{Analisis Deskriptif Data Kualitas Pembelajaran Guru PKn}

Berdasarkan data Kualitas pembelajaran guru yang diperoleh, selanjutnya dilakukan analisis menggunakan bantuan komputer program Statistik SPSS 17.0 for windows dengan tehnik analisis deskriptif frekuensi sehingga diperoleh hasilnya sebagai berikut: rerata $($ mean $)=153,62, \quad$ modus $($ mode $)=155$, median $=155$, simpangan baku (standar deviasi) $=7,11$, varians $=50,58$, nilai terendah $=139$ dan nilai tertinggi $=167$.

Berdasarkan identifikasi kategori variabel persepsi siswa tentang kualitas pembelajaran guru menunjukkan data hasil penelitian dari 84 peserta didik didapatkan 76 peserta didik (90,48\%) menyatakan kualitas pembelajaran guru PKn 
dalam kategori sangat baik, 8 peserta didik (9,52\%) menyatakan bahwa kualitas pembelajaran guru PKn dalam kategori baik, tidak ada peserta didik (0\%) menyatakan bahwa kualitas pembelajaran guru PKn dalam kategori kurang baik dan kategori tidak baik. Hasil pengklasifikasian tersebut dapat di interpretasikan bahwa tidak ada peserta didik memiliki pandangan persepsi negatif terhadap kualitas pembelajaran guru dan 100 \% siswa memiliki pandangan persepsi positif terhadap kualitas pembelajaran guru PKn.

Dengan demikian hasil penelitian tentang persepsi siswa terhadap kualitas pembelajaran guru menggambarkan semua peserta didik (100\%) menyatakan kualitas pembelajaran yang dilaksanakan oleh guru PKn dalam kategori baik. Analisis

\subsubsection{Deskriptif Data Hasil Belajar PKn Siswa}

Berdasarkan data Hasil Belajar PKn yang diperoleh selanjutnya, dilakukan analisis menggunakan bantuan komputer program SPSS Statistik 17.0 for windows dengan tehnik analisis deskriptif frekuensi diperoleh hasilnya sebagai berikut: rerata $($ mean $)=25,79$, modus $($ mode $)=25$, median $=26$, simpangan baku (standar deviasi $)$ $=2,85$, varians $=8,12$, nilai terendah $=19$, dan nilai tertinggi $=30$

Identifikasi kecenderungan atau tinggi rendahnya hasil belajar PKn dalam penelitian ini menunjukkan hasil penelitian dari 84 peserta didik didapatkan 13 peserta didik (15,48\%) memperoleh skor hasil belajar PKn dalam kategori tidak tuntas, 71 peserta didik (84,52\%) memperoleh skor hasil belajar PKn dalam kategori Tuntas.

Dengan demikian hasil penelitian variabel hasil belajar PKn menggambarkan sebagian besar peserta didik memperoleh nilai baik (84,52\%) dan sudah memenuhi standar ketuntasan secara klasikal yakni ketercapaian hasil belajar peserta didik sebesar $80 \%$. 


\subsection{Uji Persyaratan Analisis}

\subsubsection{Uji Normalitas Data}

Hasil perhitungan uji normalitas secara keseluruhan data tersebut dengan bantuan komputer program SPSS Statistik 17.0 for windows teknik analisis deskriftif explore, diketahui nilai signifikansi untuk kedua variabel berdistribusi normal karena lebih besar dari 0,05, untuk variabel kualitas pembelajaran guru nilainya 0,071 dan variabel hasil belajar PKn nilainya 0,065. Oleh karena itu data tersebut berdistribusi normal.

\subsubsection{Uji Linearitas Data}

Hasil perhitungan uji linearitas secara keseluruhan data tersebut dengan bantuan komputer program SPSS Statistik 17.0 for windows dietahui variabel yang berhubungan hasil belajar PKn dan kualitas pembelajaran guru dapat kita ketahui bahwa nilai sig dari deviation from liniarity adalah 0,207. artinya nilai ini lebih besar dari 0,05 (0,207 > 0,05). Dengan demikian dapat disimpulkan bahwa hubungan antara variabel hasil belajar PKn dan kualitas pembelajaran guru adalah linear.

\subsection{Uji Hipotesis Penelitian}

\subsubsection{Analisis Regresi Linear}

Hasil uji hipotesis dapat dilihat pada berikut

Tabel 1. Hasil Analisa Regresi linear

\section{Coefficients $^{\mathrm{a}}$}

\begin{tabular}{|c|c|c|c|c|c|}
\hline \multirow[b]{2}{*}{ Model } & \multicolumn{2}{|c|}{$\begin{array}{c}\text { Unstandardized } \\
\text { Coefficients }\end{array}$} & \multirow{2}{*}{\begin{tabular}{|c|}
$\begin{array}{c}\text { Standardized } \\
\text { Coefficients }\end{array}$ \\
Beta \\
\end{tabular}} & \multirow[b]{2}{*}{$\mathrm{T}$} & \multirow[b]{2}{*}{ Sig. } \\
\hline & $\mathrm{B}$ & Std. Error & & & \\
\hline 1 (Constant) & $-10,266$ & 5,516 & & $-1,861$ & 0,066 \\
\hline Kualitas Pembelajaran Guru & 0,235 & 0,036 & 0,586 & 6,542 & 0,000 \\
\hline
\end{tabular}


Besarnya harga koefisien persepsi siswa tentang kualitas pembelajaran Guru (X) sebesar 0,235 dan bilangan konstanta sebesar -10,266. Berdasarkan angka-angka tersebut, maka dapat disusun persamaan sebagai berikut:

$$
\hat{Y}=-10,266+0,235 X
$$

Persamaan tersebut menunjukkan bahwa nilai koefisien X sebesar 0,235 artinya, apabila nilai persepsi siswa tentang kualitas pembelajaran guru (X) meningkat 1 poin maka nilai hasil belajar PKn (Y) akan meningkat sebesar 0,235

\subsubsection{Koefisien Determinasi $\left(\mathrm{R}^{2}\right)$}

Koefisien determinasi digunakan untuk mengetahui kemampuan variabel independen dalam menjelaskan variabel dependen. Besarnya koefisien determinasi dapat dinyatakan dalam persentase. Hasil koefisien korelasi $R=0,586$ artinya kualitas pembelajaran guru memiliki hubungan positif terhadap hasil belajar PKn. Nilai koefisien determinasi $\mathrm{R}^{2}$ sebesar 0,343 yang artinya variabel kualitas pembelajaran guru PKn mampu mempengaruhi perubahan hasil belajar PKn sebesar $34,3 \%$. Hal ini menunjukkan masih ada $65,7 \%$ faktor atau variabel lain yang mempengaruhi hasil belajar PKn selain kualitas pembelajaran guru

\subsubsection{Pengujian Signifikan Koefisien Regresi Linear dengan Uji t.}

Uji t digunakan untuk menunjukkan apakah variabel bebas yang dimaksudkan dalam model mempunyai hubungan secara signifikan dengan variabel terikat, yaitu untuk mengetahui apakah variabel kualitas pembelajaran guru (X) mempunyai hubungan secara signifikan dengan hasil belajar PKn (Y)

Hasil uji t dengan bantuan komputer program statistic SPSS 17 for windows, menunjukkan nilai $t_{\text {hitung }}$ yang diperoleh adalah sebesar 6,542 dengan nilai $\mathrm{P}=0,000$. Karena tingkat signifikan lebih kecil dari 0,05 $(\mathrm{P}<0,05)$, maka ini berarti kualitas pembelajaran guru mempunyai hubungan secara signifikan dengan hasil belajar PKn

Jadi dapat disimpulkan kualitas pembelajaran mempunyai hubungan secara signifikan terhadap hasil belajar PKn. 


\section{KESIMPULAN DAN SARAN}

\subsection{Kesimpulan}

Berdasarkan hasil analisis, data pada Bab IV dapat dikemukakan tiga kesimpulan terkait penelitian ini, ketiga kesimpulan itu adalah:

1. Secara umum dapat diketahui kualitas pembelajaran yang dilaksanakan oleh guru PKn berdasarkan persepsi siswa di SMPN 1 Liliriaja dalam kategori sangat baik.

2. Secara umum dapat diketahui hasil belajar PKn SMPN 1 Liliriaja dalam kategori baik dan sudah memenuhi standar ketuntasan secara klasikal.

3. Terdapat hubungan positif dan signifikan antara kualitas pembelajaran guru PKn dengan hasil belajar PKn peserta didik.

\subsection{Saran}

Berdasarkan kesimpulan di atas, dapat diberikan saran-saran sebagai berikut:

1. Penelitian ini memberikan informasi bahwa persepsi siswa tentang kualitas pembelajaran guru berpengaruh terhadap hasil belajar peserta didik sebesar 34,3\%. Hal ini menunjukkan bahwa hasil belajar peserta didik masih banyak dipengaruhi oleh faktor lain. Diharapkan perlu penelitian selanjutnya untuk mengetahui faktor-faktor yang mempengaruhi hasil belajar peserta didik selain yang diteliti dalam penelitian ini.

2. Dengan mengetahui adanya hubungan positif yang signifikan antara persepsi peserta didik tentang kualitas pembelajaran guru dengan hasil belajar PKn diharapkan guru dapat meningkatkan kualitas pembelajaran. Untuk meningkatkan kualitas pembelajaran guru dibutuhkan usaha-usaha kearah pembinaan secara menyeluruh terhadap kemampuan belajar mengajar.

\section{DAFTAR PUSTAKA}

Abdurrahman, M. 2003. Pendidikan Bagi Anak Berkesulitan Belajar. Jakarta: Rineka Cipta.

Arikunto, Suharsimi. 1984. Dasar-Dasar Evaluasi Pendidikan. Jakarta: PT. Bina Aksara

Azwar, Syaifuddin. 2004. Metode Penelitian. Yogyakarta: Pustaka Pelajar Bimo Walgito. 2002. Pengantar Psikologi Umum. Yogyakarta: Andi Offset. 
Crosby, P.B. 1997. Quality is Free. Newyork: McGraw-Hall.

Darsono, M.2000. Belajar dan Pembelajaran. Semarang: IKIP Semarang Press

Degeng, Nyoman sudana.1989. Ilmu Pengajaran Taksnomi Variable. Jakarta: Depertemen pendidikan dan Kebudayaan Direktorat Jendral Pendidikan Tinggi P2LPTK

Deming, W.E. 1982. Out Of The Crisis - Quality, Productivity and Competitive Position. Cambridge University Press.

Djaali \& Muljono Pudji. 2008. Pengukuran dalam Bidang Pendidikan. Jakarta: Grasindo

Eggen, P.D \& Kauchak,P.P.1988. Strategies for teacher: Teaching Content and Thinking Skill. Allyn and Bacon

Ibrahim, Muslimin. 2000. Pembelajaran Kooperatif. Surabaya: UNESS University Prees.

Iskandar, A. (2013). PENGEMBANGAN PERANGKAT PENILAIAN PSIKOMOTOR DI SEKOLAH MENENGAH KEJURUAN. Jurnal Inspiration, 3(1), 37-46.

Iskandar, A. (2016). Membangun aplikasi placement test. Jurnal Inspiration, 6(1), 65-80.

Iskandar, A. (2017). The Effect of Open Book Test Model in Improving Students ' Learning Motivation. In 2nd International Conference on Education, Science, and Technology (ICEST 2017) (Vol. 149, pp. 204-206). Atlantis Press.

Iskandar, A., \& H, M. R. (2018). ITEM QUALITY ANALYSIS INSTRUMENT IN THE COLLEGE ENTRANCE TEST IN THE VIEW OF THE EXPERT VALIDATOR. In INTERNATIONAL CONFERENCE ADRI - 5 "Scientific Publications toward Global Competitive Higher Education” (pp. 364-375). https://doi.org/10.17605/OSF.IO/KZSA5

Iskandar, A., \& Rudi, A. (2017). Penyetaraan tes soal potensi akademik berdasarkan teori respon butir menggunakan Software R di STMIK AKBA. Educational Science and Technology, 3(2), 145-152.

Mudhofir.1987. Teknologi Instruksional. Bandung: Remaja Rosdakarya.

Mulyasa. 2003. Manajemen Berbasis Sekolah. Bandung: PT Remaja Rosdakarya.

Murgatroy, S. \& Morgan Colin.1994. Total quality Management and the School. Buckingham: Open University Press.

Nurdin. 2007. Model Pembelajaran Matematika yang Menumbuhkan Kemampuan Metakognitif. Disertasi tidak diterbitkan. Surabaya: UNESA

Purwanto.2008. Evaluasi Hasil Belajar. Surakarta: Pustaka pelajara

Piaget, Jean.1988. Antara Tindakan dan Pikiran. terjemahan Agus Cremers. Jakarta: PT. Gramedia.

Rakhmat, J. 2001. Psikologi Komunikasi. Bandung: PT. Remaja Rosdakarya.

Ruslan. 2009. Validitas Isi; Buletin Pa’biritta No. 10 Tahun IV September 2009.

Sallis, Edward. 2002. Total Quality Managemen in Education $3^{\text {th }}$. London: Kogan Page 
Slameto. 2003. Belajar dan Faktor-faktor yang Mempengaruhinya. Jakarta: Rineka Cipta.

Slavin, R.E.2008. Cooperative Learning. Bandung: Nusa Media

Sudjana, Nana.1991. Dasar-dasar Proses Belajar Mengajar. Bandung: Sinar Baru.

Sudjana, Nana.2010. Penilaian Hasil Proses Belajar Mengajar. Bandung: Remaja Rosdakarya.

Sukamto, et al.(2009). Pengembangan profesi guru secara berkesinambungan Sebagai strategi nasional pendukung sertifikasi guru.Yogyakarta: Lembaga Penelitian IKIP Yogyakarta

Susetyo Budy.2011.Menyusun tes hasil belajar. Bandung: CV Cakara Kompleks Bojong Malaka Indah

Sobur, Alex. 2003. Psikologi Umum. Bandung: Pustaka Setia.

Tjiptono, Fandy.2005. Prinsip Total Quality Service. Yogyakarta: Andi offset

Winkel, W. S.2004. Psikologi Pengajaran. Yogyakarta : Media Abadi

Yusuf Tayibnapis, Farida. 2008. Evaluasi Program dan Instrumen Evaluasi. Jakarta: Rineka Cipta. 